Images in...

\title{
Large skull metastasis of follicular thyroid carcinoma
}

\author{
Tsutomu Yamada, ${ }^{1}$ Fumiko Yokota, ${ }^{1}$ Yuko Yambe, ${ }^{1}$ Yasuhisa Kato, ${ }^{1}$ Suzuko Moritani, ${ }^{2}$ \\ Masaki Hasegawa, ${ }^{2}$ Shu Ichihara, ${ }^{2}$ Yasuyuki Sato, ${ }^{3}$ Noriyuki Susaki ${ }^{4}$
}

${ }^{1}$ Department of Endocrinology and Diabetes, Nagoya Medical Center, Nagoya, Japan;

2Department of Pathology, Nagoya Medical Center, Nagoya, Japan;

${ }^{3}$ Department of Surgery, Nagoya Medical Center, Nagoya, Japan;

${ }^{4}$ Department of Neurosurgery, Nagoya Medical Center, Nagoya, Japan

Correspondence to Tsutomu Yamada, yamadat@nnh.hosp.go.jp

\section{DESCRIPTION}

A 62-year-old woman presented with gradual enlargement of a tumour mass on her head. She had first noticed it about 2 years previously, but it had started to enlarge several months before she came to our clinic. She was alert but reported mild headache and nausea. We found a large soft and elastic tumour on the left temporal and occipital region of her head. Thyroid tumour was undetected on palpation. Head CT and brain MRI revealed a large tumour; three-dimensional CT showed skull bone destruction (figure 1). CT also revealed a calcified tumour in the right thyroid lobe, small granular pulmonary shadows and osteolysis in the right pubic bone (figure 2). Based on fine-needle aspiration biopsy (FNAB) of the thyroid tumour, follicular neoplasm was suspected. Serum thyroglobulin level was $89177.1 \mathrm{ng} / \mathrm{ml}$ $(0.0-100.0 \mathrm{ng} / \mathrm{ml})$. We performed tumourectomy of the head and total thyroidectomy. Histopathological examination showed follicular thyroid carcinoma (FTC) with skull metastasis (figure 3). Following surgery, the patient's serum thyroglobulin level was reduced to $22932.3 \mathrm{ng} / \mathrm{ml}$ and her headache and nausea disappeared. She experienced no disorientation, paralysis or gait disorder and at follow-up 1 -year after surgery she was asymptomatic.
FTC occasionally develops distant metastases to the lungs and bones but it is less likely to metastasise to the skull. ${ }^{1}$ Some cases of FTC metastasising to the skull have been reported, ${ }^{2} 3$ but the present case is rare and unique due to the shape and size of the skull base metastatic tumour. This patient was diagnosed with a thyroid tumour approximately 20 years ago but failure to follow-up gradually led to multiple metastases to the skull, lungs and pubic bone. FTC by FNAB is difficult to diagnose, therefore we must carefully observe the size of thyroid tumours and distant metastasis at follow-up.

Competing interests None.

Patient consent Obtained.

\section{REFERENCES}

1. Boehm T, Rothouse L, Wartofsky L. Metastatic occult follicular thyroid carcinoma. JAMA 1976;235:2420-1.

2. Portocarrero-Ortiz L, Garcia-Lopez R, Romero-Vargas S, et al. Thyroid follicular carcinoma presenting as skull and dural metastasis mimicking a meningioma: a case report. J Neurooncol 2009;95:281-4.

3. Shamim MS, Khursheed F, Bari ME, et al. Follicular thyroid carcinoma presenting as solitary skull metastasis: report of two cases. J Pak Med Assoc 2008; 58:575-7.

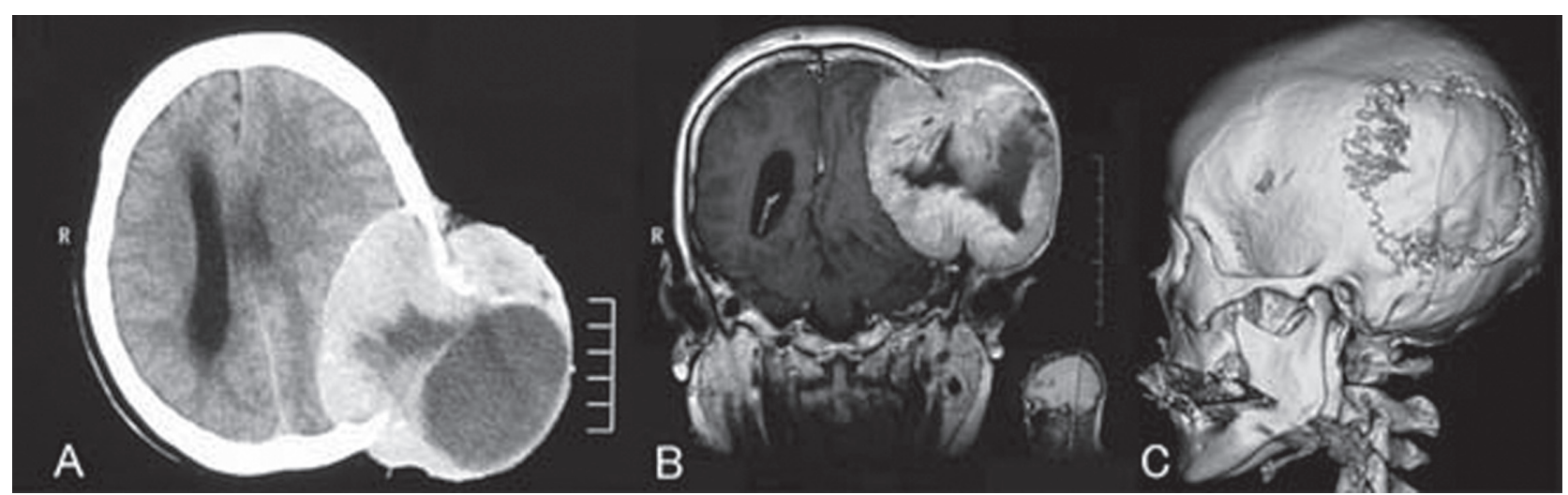

Figure 1 Head CT ( $A$, transverse section) and T1-weighted brain MRI and ( $B$, coronal section) showing a large tumour in the posterior left region of her head measuring $11.4 \mathrm{~cm}$ at its greatest diameter. The brain was compressed with reduction in the size of the cerebral ventricles. Three-dimensional CT (C) showing skull bone destruction. 


\section{BMJ Case Reports}

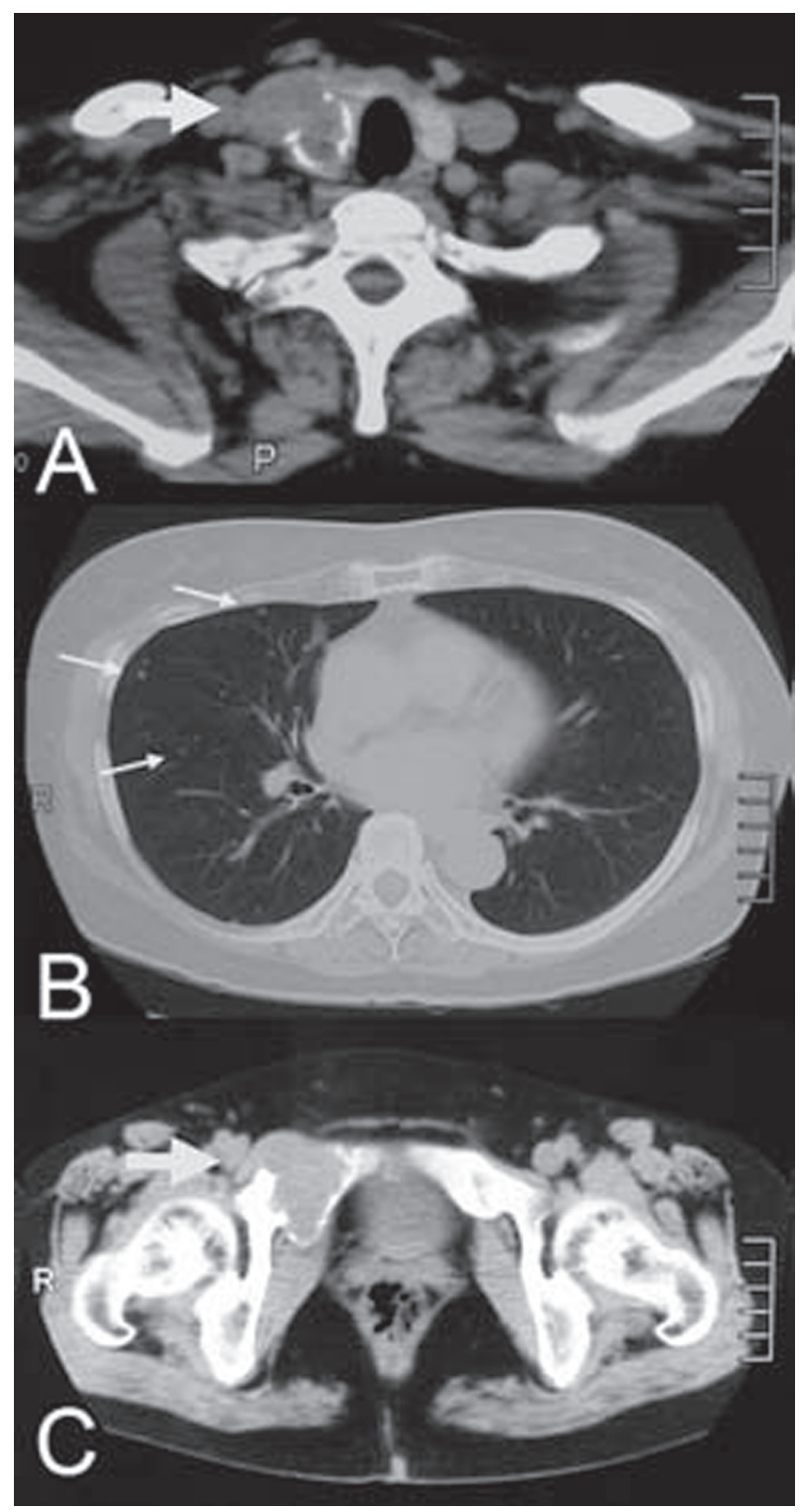

Figure 2 CT showing a calcified tumour with an irregular border in the right thyroid lobe $(2.8 \times 3.0 \mathrm{~cm})(\mathrm{A})$ small granular pulmonary shadows $(B)$ and osteolysis in the right pubic bone $(C)$.

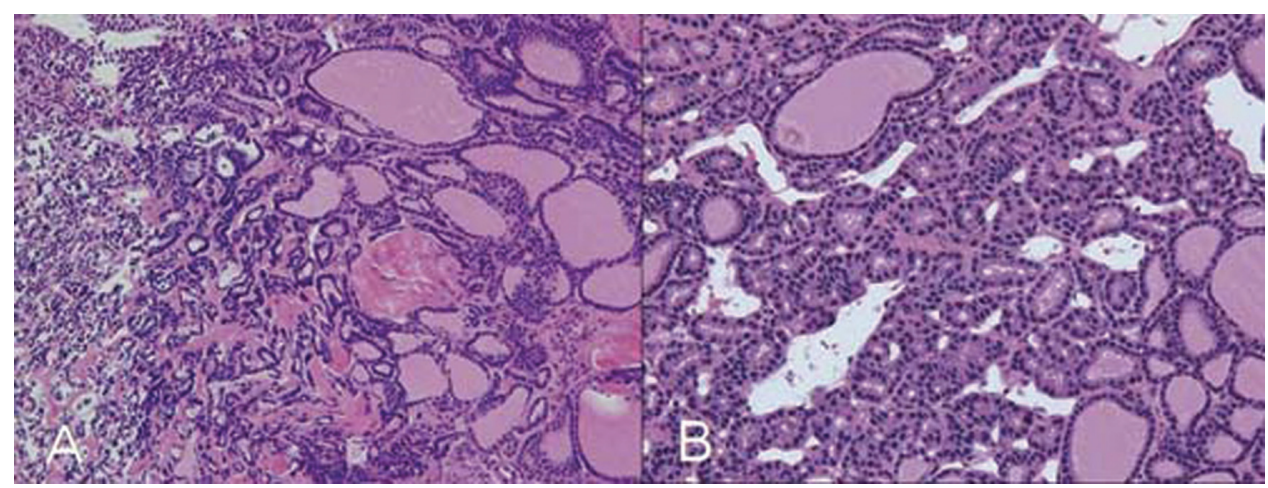

Figure 3 Photomicrograph of the surgical specimen. Tissue removed from the skull base tumour (A) showing structure of the thyroid follicle. Metastatic thyroid carcinoma was suspected. Thyroid tumour (B) showing follicular thyroid carcinoma with follicle cell proliferation, nuclear enlargement and hyperchromasia (H\&E stain). 


\section{BMJ Case Reports}

This pdf has been created automatically from the final edited text and images.

Copyright 2011 BMJ Publishing Group. All rights reserved. For permission to reuse any of this content visit http://group.bmj.com/group/rights-licensing/permissions.

BMJ Case Report Fellows may re-use this article for personal use and teaching without any further permission.

Please cite this article as follows (you will need to access the article online to obtain the date of publication).

Yamada T, Yokota F, Yambe Y, Kato Y, Moritani S, Hasegawa M, Ichihara S, Sato Y, Susaki N. Large skull metastasis of follicular thyroid carcinoma. BMJ Case Reports 2011;10.1136/bcr.11.2010.3518, date of publication

Become a Fellow of BMJ Case Reports today and you can:

- Submit as many cases as you like

- Enjoy fast sympathetic peer review and rapid publication of accepted articles

- Access all the published articles

Re-use any of the published material for personal use and teaching without further permission

For information on Institutional Fellowships contact consortiasales@bmjgroup.com

Visit casereports.bmj.com for more articles like this and to become a Fellow 